\title{
What Should a Good Feminist Theory of Equality Be? A Critique of Ronald Dworkin*
}

\author{
Kim, HeeKang \\ (Kyung H ee University)
}

$\langle$ CONTENTS〉

I . Introduction

II. Why Luck Egalitarianism?

III. The Systemic Injustice of Gender

IV. Limits of Luck Egalitarianism

1. Women's Luck

2. Women's Choice
3. The Systemic Relationship between Women's Luck and Women's Choice

V. Conclusion: Toward a Feminist Theory of Equality

- Keyword: Ronald Dworkin, luck egalitarianism, gender inequality, gender division of labor, social justice, theory of equality

\section{【ABSTRACT】}

Luck egalitarianism is one of most significant forms of distributive egalitarianism in contemporary egalitarian justice theory. Luck egalitarians share one core idea: the distinction between luck and choice is of crucial importance for justice. This paper examines luck egalitarianism from a feminist perspective. Focusing on gender inequality generated by the gender division of labor in the family, I criticize luck egalitarianism for failing to address properly the injustice of gender inequality generated by the gender division of labor. My discussion of luck egalitarianism is primarily concerned with Ronald Dworkin's theory of equality. I argue that luck egalitarians' concepts of luck and choice do not rightly capture the gendered social structure and women's choices contextualized within such a structure, respectively. I also argue that the luck-choice distinction is not an adequate device for considering the injustice of gender arising from the systemic relationship between the gendered social structure and women's choices. Given my critiques of luck egalitarianism, I offer a brief outline of what a better feminist theory of equality should be.

\footnotetext{
*This research was funded by the Center for the Reconstruction at Human Society of Kyung Hee University, Seoul, Korea.
} 


\section{I . Introduction}

Luck egalitarianism is one of most significant forms of distributive egalitarianism in contemporary egalitarian justice theory. ${ }^{1)}$ Such theorists Ronald Dworkin, Richard Arneson, G. A. Cohen, John Roemer, and Eric Rakowski are included in this family of egalitarians. Their theories share one core idea: the distinction between luck and choice is of crucial importance for justice. That is, luck egalitarians distinguish two aspects of a person's condition: luck and choice. While the former is the aspect of a person's condition beyond her control such as race, gender, ethnicity, and so on the latter is the aspect of a person's condition under her control. Given this distinction, they stipulate that inequalities deriving from the effects of luck are unjust, and such inequalities are the legitimate subjects of social rectification. They, on the other hand, argue that inequalities deriving from the outcomes of choices that people voluntary make are just, and people should be held responsible for such inequalities. For example, if people experience disadvantage or discrimination because of their being blind or lacking talent, since blindness and lack of talent are elements of luck beyond their control, society, as far as possible, should take responsibility for compensating those people for the disadvantage or discrimination that they suffer. On the other hand, people who become poor because they choose not to work or prefer to have leisure rather than to work are not entitled to any compensation. They should be held responsible for the poverty since the poverty that they undergo is just.

This paper examines luck egalitarianism from a feminist point of view. With the great influence that this new line of thought has brought to current scholarship on egalitarian justice, there has been much literature that critically examines the luck-egalitarian theorization of equality although little work has done from a feminist perspective. ${ }^{2)}$ An exception is Elizabeth Anderson's "What is the Point of Equality?" ${ }^{\text {) }}$ Anderson criticizes the luck-egalitarian distinction of luck/choice for failing to capture the "vulnerability of the dependent caretakers" to exploitation, violence, and domination. ${ }^{4)}$ According to

1) The name "luck egalitarianism" was first coined by Elizabeth Anderson. See Elizabeth Anderson, "What Is the Point of Equality?" Ethics, 109 (1999): 287-337.

2) For critiques of luck egalitarianism, Anderson, "What Is the Point of Equality?"; Samuel Scheffler, "What is Egalitarianism?" Philosophy \& Public Affairs 31 (2003): 4-39; Jonathan Wolff, "Fairness, Respect, and the Egalitarian Ethos," Philosophy \& Public Affairs 27 (1998): 97-122; Timothy Hinton, "Must egalitarians Choose Between Fairness and Respect?" Philosophy \& Public Affairs 30 (2001): 72-87.

3) Anderson, "What Is the Point of Equality?"

4) Ibid., pp.297-8. 
Anderson, the luck-egalitarian theorization of equality cannot adequately address those choices and responsibilities of the dependent caretakers that are conditioned by socially imposed factors. Although I do value Anderson's point on dependent caretakers, who are mostly women, her overall accounts are not particularly gender-centered. Anderson's critique is well taken, but it falls short of providing a substantive feminist analysis on luck egalitarianism, which this paper intends to provide.

I am particularly interested in gender inequality generated by the gender division of labor in the family. I am concerned with the situation of unmarried, married, or divorced women who play a dual role as primary caretakers of children and other dependents and as labor market workers in the workplace outside the home. Of course, subjects of sexuality and sexual preferences are important issues of gender in the discussion of equality. Yet, I think that the major injustice of gender comes from the unequal situation of those women. Also, given the reality that 72.3 percent of women with children under age 18, 64.6 percent of women with children under age 6 , and fully 76 percent of single mothers participated in the labor force in 2000 in the U.S., ${ }^{5}$ those women in whom I am interested do not comprise a small number of women. Rather, the situation and experience of those women represent the everyday lives of a majority of women.

In this paper, I characterize the gender inequality that those women experience as being systemic, and I criticize luck egalitarianism for failing to address properly the systemic injustice of gender. My discussion of luck egalitarianism is primarily concerned with Ronald Dworkin's theory of equality as a representative form of luck egalitarianism. ${ }^{6}$ I argue that luck egalitarians' concepts of luck and choice do not rightly capture the gendered social structure and women's choice, respectively. I also argue that the luck/choice distinction is not an adequate device for considering the injustice of gender

5) Bureau of Labor Statistics, Employment and Earnings, January 2001, recited from New Strategist Editors, American Women: Who They Are \& How They Are, $2^{\text {nd }}$ edition (Ithaca, New York: New Strategist Publications, Inc., 2002), pp.240-43.

6) I consider Dworkin's theory of "equality of resources," which appeared in his famous article of 1981, to be the first move toward the luck-choice normative formation of equality theorization. This article reappeared in his book, Sovereign Virtue (Cambridge, MA: Harvard University Press, 2000). Arneson's and Cohen's theories of equality are actually critiques of Dworkin's. In response to his resource-based equality, Arneson and Cohen propose welfarebased theories of equality? "equal opportunity for welfare" and "equal access to advantage," respectively. Dworkin, Arneson, and Cohen have participated in "equality of what" debate, which was initially raised by Amartya Sen in his celebrated 1979 lecture. Dworkin, Arneson, and Cohen disagree with each other to some degree regarding where to draw a line between luck and choice. Yet, they all basically agree with each other that the luck-choice framework is a normative device for the realization of egalitarian justice. 
arising from the systemic relationship between the gendered social structure and women's choice. .) Given my critiques and reformulations of luck egalitarianism, I offer a brief outline of what a good feminist theory of equality should be.

I begin by discussing the importance of luck egalitarianism for a feminist concern. Next, I explore general features of gender inequality generated by the gender division of labor in the family and characterize it as the systemic injustice of gender. Then, I examine how luck egalitarianism fails to address the systemic injustice of gender.

\section{Why Luck Egalitarianism?}

Why do feminists need to care about luck egalitarianism? Why does luck egalitarianism require special feminist attention? First, my general answer relies on Susan Okin's account on social justice regarding the issue of gender. According to Okin, gender inequality is one of major injustices in our society, and a full theory of justice should properly address gender inequality. She criticizes many leading equality and social justice theories for ignoring the issue of gender in their theorization. She laments "[H]ow can theories of justice that are ostensibly about people in general neglect women, gender, and all the inequalities between sexes?" ${ }^{8)}$ I fully agree with Okin. To be a full theory of justice, I believe, any justice theory should first confront the question of "[H]ow justice is gender." ${ }^{9)}$ Concerning this, luck egalitarianism should not be an exception, and thus deserves close feminist scrutiny.

Second, more notably, feminist interest in luck egalitarianism has to do with a principal objective that luck egalitarianism aims to achieve. As Samuel Scheffler rightly points out, luck egalitarianism appeared during last two decades when the increased normative concern for diversity such as gender, race, religion, and ethnicity coincided

7) In fact, few researches have been done on the feminist critique of Ronald Dworkin's equality theory with the exception of Anderson's "What Is the Point of Equality?" and Andrew Mason's "Equality, Personal Responsibility, and Gender Socialisation," Proceedings of the Aristotelian Society, vol.100 (2000): 227-46. While Anderson's and Mason's studies primarily focus on the aspect of women's choice, this paper concerns both aspects of women's luck and women's choice and, most importantly, the systemic relationship between women's luck and women's choice. In the Korean scholarship, Hee-Kang Kim's research also deals with the feminist critique of Dworkin's theory with respect to its conceptualization of autonomy, but it broadly relates its critique along with those of other luck egalitarian conceptualizations of autonomy. See Hee-Kang Kim, "A Feminist Critique of the Luck Egalitarian Concept of Autonomy," Korean Political Science Review, vol.42, no.3 (Fall 2006): 79-101 [Korean].

8) Susan Okin, Justice, Gender, and the Family (New York: Basic Books, 1989), p.8.

9) Ibid., p.8. 
with the strong reliance on individual autonomy and liberty. ${ }^{10)}$ In this trend of the times, luck egalitarianism intends to accommodate diversity issues, such as feminism, while retaining the liberal framework to some degree. This objective is fundamentally grounded in the luck/choice distinction that luck egalitarians propose. Luck egalitarians believe that the idea of luck and relevant social responsibility yield a substantive account of equality that normatively accommodates diversity issues; that, at the same time, the notion of choice and relevant personal responsibility highlight individual autonomy and liberty. That is, the luck/choice distinction enables luck egalitarians to achieve such a double-sided objective. Thus for luck egalitarians, luck and choice, social responsibility and personal responsibility, and equality and liberty are not conflicting notions. Rather, they are compatible with each other within the luck/choice framework.

Significantly, therefore, luck egalitarians claim that through the luck/choice distinction, gender injustice can be successfully incorporated into their equality discussion. Dworkin, for example, specifically uses the luck/choice distinction as a device to criticize real-world injustices. He specifies that one of the greatest problems of current American society is social stratification based on gender, race, and talent: women, blacks and the handicapped are often excluded from the highest ranks of income, wealth, power, prestige, and authority. According to Dworkin, if such inequalities result from factors of gender, race, and handicaps (and/or discrimination based on gender, race, and the natural lack of talents), the inequalities are unjust. Since people's "gender, race, or particular sets of skills and handicaps" are aspects of luck beyond their control, their fates should be "insensitive" to those effects of luck. ${ }^{11)}$ On Dworkin's account, implementing his theory of "equality of resources," which neutralizes the effects of luck in the distribution of resources, would ultimately solve such inequality problems of gender.

Luck egalitarians, however, do not say that all inequalities of gender are simply unjust. They stipulate that some inequalities of gender deriving from the choices that women voluntarily make are acceptable. In particular, Arneson emphasizes the outcomes of women's choices and preferences in egalitarian family justice. ${ }^{12)}$ He claims that family justice should be achieved in a way that respects the difference between husband and wife in their preferences, values, and aspiration. That is, if a wife has a strong preference for laundering and taking care of children rather than for doing paid labor in the market and if husband has a strong preference for doing paid labor rather

10) Scheffler, "What is Egalitarianism?" pp.14, 38-9.

11) Ronald Dworkin, Sovereign Virtue (Cambridge, Mass.: Harvard University Press, 2000), p.6.

12) Richard Arneson, "Feminism and Family Justice," Public Affairs Quarterly 11 (1997): 313-330. 
than doing housework, then the distribution of paid and unpaid work should be arranged in a way to maximally satisfy the husband's and wife's preferences and choices. Thus, if women have more burdens of housework and child care than men do due to the choices driven by their preferences, this inequality of gender is a just inequality for which women should held to be responsible.

Therefore, I argue that the importance of luck egalitarianism for feminists critically lies in the viability of the luck/choice distinction in its application to gender injustice. I do not think that luck egalitarianism simply neglects the issue of gender. Rather, it indeed seriously considers gender inequality as a central concern of social justice. My question is whether the luck/choice distinction is really a useful device to address gender injustice, as luck egalitarians claim. If yes, then luck egalitarianism succeeds in attaining its fundamental goal: the luck/choice distinction could potentially provide a new blueprint for the feminist theorization of equality. If no, luck egalitarianism fails in achieving its goal: feminists need an alternative normative account for gender equality. I will return to this question in the section $\mathrm{I}$.

\section{The Systemic Injustice of Gender}

Understanding the actual lives of women and the injustices they face should not only take precedence over, but also should be the foundation of all feminist inquiries and criticisms. For the purpose of examining and characterizing the situation of women, from which the major issues of gender injustice arise, I focus on the unequal situation of women at work and in the family, which is generated by the gender division of labor in the family. I characterize such inequality as being systemic, and I argue that the systemic injustice of gender is engendered by a relationship between the gendered social structure grounded in the gender division of labor and women's choices within the structure. Let me illustrate the systemic injustice of gender generated by the gender division of labor in the family.

The gender division of labor in the family does not simply denote the gender-based separate labor assignments in the household. Instead, it has broad social, economic, and cultural implications, that is, it is an aspect of social structure. The gender division of labor in the family involves the gender-based separate organization of market work and family work. The labor market is designed for "ideal workers" (mostly men) who work full time or overtime and do not have primary responsibilities for housework and child caring. On the other hand, women are still often considered to have primary responsibilities for 
family work and child caring. This separate organization of market work and family work also entails distinct gender role expectations and ideologies (e.g. men as breadwinner vs. women as homemaker) and different characterizations of men's work and women's work (e.g. earning money vs. nursing and caring). The gender division of labor is justified, maintained, and reproduced through social norms, practices, and customs. ${ }^{13)}$ In other words, the gender division of labor is not a formal socio-economic and/or legal institution. It is a form of social structure that includes all aspects of role expectations and ideologies, social rules and norms, cultural customs, socialization, and education.

The injustice of the gender division of labor arises because this separate organization of market work and family work (the occupational differentiation between the genders) results in the status inequality of gender, by disadvantaging women as a group while privileging men as a group. The gender division of labor not only causes the marginalization of women in the labor market, but also, more broadly, engenders the overall unequal situation of women relative to men in the socioeconomic and political domains. Given that the organization of the labor market is fundamentally structured around the idea of the "ideal-worker norm," those women who have responsibilities for housework and child caring cannot compete with "ideal workers" (mostly men) on equal terms. Childcare and household responsibilities, for example, often induce women to seek more convenient and less-energy intensive occupations, such as part-time and/or temporary jobs. Women workers are more likely to be "trapped in part-time positions with low pay and few benefits," as Deborah Rhode puts $\mathrm{it}^{14)}$ and "funneled into lowpaying, low status-job." ${ }^{15)}$ This unequal situation of women in the work force reflects and reinforces the unequal situation of women in the family, and this leads to a vicious cycle of inequality of gender.

In the U.S., although women represent almost half of the labor force, white men still held almost 96 percent of the top earning position in Fortune 500 companies in 2000, and there were only two women CEOs. ${ }^{16)}$ A majority of law school students are women, but women only account for about 15 percent of federal judges and law firm partners, 10

13) Joan Williams, Unbending Gender: Why Family and Work Conflict and What to Do About It (Oxford: Oxford University Press, 2000).

14) Deborah Rhode, Speaking of Sex: The Denial of Gender Inequality (Cambridge, Mass.: Harvard University Press, 1997), p.142.

15) Diana Furchtgott-Roth and Christine Stolba, Women's Figure: An Illustrated Guide to the Economic Progress of Women in America (Washington, D.C., AEI Press, 1999), p.33.

16) Catalyst, 2000 Catalyst Census of Women Corporate Officers and Top Earners (New York: Catalyst Publication, 2000), p.8. 
percent of law school deans and general counsels, and 5 percent of managing partners of large firms. ${ }^{17)}$ Instead, a larger proportion of women workers are concentrated in certain categories of jobs. In 2002, among full-time workers, women accounted for 99 percent of secretaries and kindergarten teachers, 98 percent of child care workers, 93 percent of registered nurses, and 83 percent of elementary school teachers. ${ }^{18)}$ These are usually low wage, less autonomous, and dead-end jobs. In 2000, 81.8 percent of parttime workers were women. ${ }^{19)}$ Not only are women underrepresented at the highest levels of occupational status, they are also underrepresented in terms of financial reward. According to a recent research by the Families and Work Institute, the median hourly earnings of women (\$12.50) are significantly lower than men's median hourly earnings (\$16.32) by nearly four dollars per hour. Women earn 77 percent of what men earn on a median hourly basis. ${ }^{20)}$ The high rate of poverty among women and children also has to do with the impact of the gender division of labor. In 2000, 32.5 percent of femaleheaded family (with no spouse present) with children were in poverty. ${ }^{21}$ Women account for 57 percent of people living in poverty ${ }^{22)}$; one-fifth of all children are poor. ${ }^{23)}$ Nearly 80 percent of the poor are women and children. ${ }^{24)}$

Although this gendered social structure is an important element in describing gender inequality, it does not comprise the whole picture. This is because the system of gender encompasses not only the gendered social structure, but also women's choice. A system is comprised of agents as actors who can respond to social structure and social relationships and form their lives. Choice, however, does not exist independent from social structure. The choices and behavior of agents are inevitably contextualized within the social structure.

Concerning the contextualized preferences and choices of women who are situated at

17) Deborah Rhode, "Gender and the Profession" The No-Problem Problem," Hofstra Law Review, vol.30. (2001), p.1002.

18) Bureau of Labor Statistics, Employment and Earnings, January 2001, recited from New Strategist Editors, American Women, pp.249-59.

19) Ibid., p. 239.

20) The Families and Work Institute, Highlights of the National Study of the Changing Workforce, no.3 (2002), pp.8-9.

21) Bureau of the Census, Current Population Surveys, recited from New Strategist Editors, American Women, p.229.

22) Ibid., p.227.

23) Curtis Berger and Joan Williams, Property: Land Ownership and Use (New York: Aspen, 1997), p.41.

24) Joan Williams, "Notes of a Jewish Episcopalian: Gender a language of Class, Religion as a Dialect of Liberalism," in Anita Allen \& Milton Regan eds., Debating Democracy's Discontent: essays on American Politics, Law, and Public Philosophy (Oxford: Oxford University Press, 1998). 
work and in the family, there are various factors of the gendered social structure that shape women's making choices in their career and housework decision. These factors include such things as gender role ideology, which classifies men as breadwinners and economic providers and woman with homemakers and caregivers; social institutions and organizations designed for full-time workers regarding working hours and location; sex-role socialization through media and family environment that express genderrelated values and attitudes; a formal educational system that trains boys and girls in favor of maintaining gender stereotypes and traditional sex roles; cultural customs that grant different social rules and norms for the genders; working environment and culture in the labor market that intentionally and unintentionally discriminate against women workers in terms of promotion opportunities, wage differences, and work assignments; and gender-biased governmental policies and programs that cause the massive dismissal of women workers. Although these may not comprise a complete list for fully illuminating women's contextualized choices at work and in the family, career and housework decisions for many individual women are not the product of independent and voluntary preferences, but the result of influences of these multiple factors. Thus, it is simply wrong to say that individuals can make "voluntary" or "genuine" choices free from the influence of social structure and circumstances, as human capitalists claim. ${ }^{25}$ Rather, individual women's reasons for making choices are complex, but they show up in a collective and patterned way.

Similarly, some feminists such as Nancy Folbre and Ingrid Robeyns also illustrate various elements of social structure (e.g. gender ideology, relative resources of the spouses, time availability, etc.) that have influence on women's occupational and housework decisions. I basically agree with Folbre and Robeyns that the formation of women's preferences and choices are influenced by manifold factors of the gendered social structure. However, there is an important point with which I have a problem: they do not particularly take account of women's agency. In describing contextualized women's choices within the gendered social structure, they claim that women's choices are constrained by social structure, which they call "gendered constraints." ${ }^{26)}$ So, they consider women's choices as passive choices merely determined by the gendered social structure. In contrast, I argue that women's choices are positively constructed by and

25) For human capitalists' idea of women's choice regarding the gender division of labor, see Gary Becker, A Treatise on the Family (Cambridge, Mass.: Harvard University Press, 1981).

26) Nancy Folbre, Who Pay for the Kids?: Gender and the Structures of Constraint (London and New York: Routldge, 1994). Ingrid Robeyns, "Does the Gender Division of Labor Result in Unjust Inequalities?" Paper Presented at the 2003 Annual Meeting of the American Political Science Association, Philadelphia, August 28-August 31. 
through the gendered social structure. Here I want to adopt an interpretation of the self and agency that has been proposed by some relational autonomy theorists including Jennifer Nedelsky and Marilyn Friedman. According to them, social circumstances and relationships not only are necessary for forming a person's self, but also actually contribute to constituting the self.

The most important feature of analyzing gender as a system, therefore, lies in the relationship between social structure and agency. The systemic analysis of gender rejects a simple dichotomy between social structure and agency. As Anthony Giddens notes, "structure is always both enabling and constraining [agency], in virtue of the inherent relation between structure and agency," which he calls "the duality of structure." ${ }^{27)}$ The gendered social structure and women's agency are not exclusive at all. Gender inequality arises neither from the problem of the gendered social structure nor as an outcome of women's choices. Rather, the unequal situation of women at work and in the family results from the injustice of the system of gender as a whole - the "inherent relation" between a social structure based on the gender division of labor in the family and women's choices contextualized within such a structure.

\section{Limits of Luck Egalitarianism}

I earlier asked whether the luck/choice distinction is a useful device to address gender injustice. My answer is in the negative. I argue that (1) the luck-egalitarian concepts of luck and choice fail to include the gendered social structure and contextualized women's choice, respectively; (2) the luck/choice distinction fails to address the systemic relationship between the gendered social structure and contextualized women's choices within the structure.

\section{Women's Luck}

If the luck/choice distinction is critical in the consideration of justice, one significant question that we can ask is what the components of luck and choice are. That is, the crux of luck egalitarianism lies not only in the luck/choice distinction itself, but also in identifying the contents of the distinction. The contents of luck and choice essentially determine the characteristics of luck egalitarianism. Therefore I define here factors that

27) Anthony Giddens, The Constitution of Society: Outline of the Theory of Structuration (Berkeley and Los Angeles: University of California Press, 1984), p.169. 
luck egalitarians identify with luck and choice and see if such factors properly address the luck and choice of women situated in the family and at work.

Regarding the luck-egalitarian idea of luck, I focus on Dworkin's concept of luck developed in his theory of "equality of resources." Dworkin explicitly describes several factors of (brute) luck, that is, the aspect of a person's condition beyond her control. According to Dworkin, a person's luck significantly includes "personal resources" such as "physical and mental health and ability." ${ }^{28)}$ In addition, he says that people's luck includes "their economic backgrounds, gender, race, or particular sets of skills and handicaps." ${ }^{29)}$ At some point, he also states that a person's bad luck is "to be born into a relatively poor family or a family that is selfish or spend thrift." ${ }^{30)}$ The primary purpose of his "equality of resources" is to distribute resources in a manner sensitive to people's choices but insensitive to their "personal resources" and those other sorts of luck.

For this purpose, Dworkin provides a hypothetical insurance market as a way to neutralize the influence of luck in distributing resources. In the market, it is assumed that people are situated behind a modified veil of ignorance where each person has the perfect knowledge of society as well as of her personality, such as tastes, preferences, and ambitions, but she does not know the possible bad luck that might happen to her in real society; it is also assumed that people share an equal amount of resources and that with these equal resources, they insure some of their initial resources against the possible bad luck. People's decisions regarding whether or not to insure against what kinds of luck are made based on their tastes and preference. The availability of an insurance market thus does give everyone an equal opportunity to mitigate the ill effects of luck by insuring against them, while it does not trespass the choice-sensitive principle.

Consider a case of handicaps that Dworkin offers. In a hypothetical insurance market for handicaps, people do not know whether they are handicapped or not in the actual society, but it is assumed that they are equally aware of the susceptibility of the various sorts of handicaps that might happen to them. The basic formulation of the insurance market for handicaps is grounded in the counter-factual assumption that able-bodied persons imagine what the life circumstances of handicapped persons are, then calculate the types and amounts of insurance handicapped persons would purchased if they were not handicapped. If, for example, I want to be a music composer in the future and so think that hearing is most important for me, I would insure many of my resources against deafness, not blindness.

28) Dworkin, Sovereign Virtue, p.322.

29) Ibid., p.6.

30) Ibid., p.347. 
How then does Dworkin's hypothetical insurance market apply to a case of gender? Along with personal resources such as handicaps, as I mentioned earlier, Dworkin does consider gender as an element of luck. Unfortunately, Dworkin does not specify a case of gender in the design of hypothetical insurance markets. He, however, seems to suppose the following features. Since people know their personalities in insurance markets, they, too, likely know their genders. ${ }^{31)}$ Also, since they have a perfect knowledge of society, they can imagine the possible experience they would have as being a woman or man in society. And people's insurance decisions would depend on their particular personal preferences and tastes. For example, those women who want to be CEOs or doctors would insure larger amount of money against not achieving their goals than those women who want to be homemakers or nurses would. This is because, with their full knowledge of society, they could anticipate that there are relatively few CEOs or doctors compared to female homemakers or nurses in society, and that it is relatively more difficult and less likely for women to be CEOs or doctors than homemakers or nurses.

Given this feature, can we say that Dworkin's hypothetical insurance market for gender successfully neutralizes the ill effects of gender? Does Dworkin's concept of luck properly take into account the social structure, which is grounded in the gender division of labor in the family? I think it does not. As I showed earlier, the essence of the gendered social structure lies not only in the separate organization of market work and family work, but also in the distinct characterizations of men's work and women's work and the different value judgments regarding their work. That is, women and men have different occupations, and those occupations are given different values. Often so-called women's work at home, such as housework and child caring, is lowly valued. They are not generally financially compensated on the market at all, or are poorly compensated. They are not even regarded as "real" work. In the current monetary society, unpaid work, which most women do, is directly tied to the overall low status of women with regard to wealth, honor, power, and prestige. Also, typical female jobs in the labor market, such as that of daycare worker, baby-sitter, waitress, nurse, typically are given little respect and are poorly paid. The low value of those "female" jobs significantly reflects the low value given by society to the "unreal" work of women at home. In contrast, work in the labor market, which most men do, does usually receive formal monetary compensation. Such work is generally valued as "real" work. The society is

31) It is questionable whether people know their genders in hypothetical insurance markets. However, considering that Dworkin notes the problem of prejudice based on gender and race in the markets, which I will not discuss in detail in this paper, it is assumed that people know their genders in Dworkin's scheme. 
designed to suit "real" workers, assuming that "real" workers have someone at home to do the "unreal" work.

The gendered social structure, therefore, can be essentially characterized as a social system of value accorded to the differences of occupations held by the genders. It puts low value on the housework that women primarily do, while it puts high value on the market work that men primarily do. It unfairly conditions the life chances and prospects of women, while it privileges those of men. However, it is not my aim here to demand that women's housework and child caring at home be financially compensated at the same rate as men's market work; nor do I intend to point out the fault of the market mechanism itself that fails to give people what they deserve. Instead, my aim is to point out the injustice arising from the social system of value regarding women's work and men's work that is institutionalized in major institutions and social practices of our current society. I argue that society should fairly recognize devalued (or under-valued) women's work that inevitably needs to be done, even though the market is not designed to do so.

I thus argue that Dworkin's concept of luck fails to include this social system of value as an aspect of luck, for which no one is especially responsible. Simply categorizing gender as an element of luck is not sufficient to address the effect of the gendered social structure. Dworkin's hypothetical insurance market for gender does not properly neutralize the ill effects of the gendered social structure that stigmatizes women and privileges men. That is, Dworkin's insurance market for gender could compensate women for inequalities deriving from their not being CEOs and doctors, but could not compensate them for inequalities deriving from differences in values associated with jobs like CEOs and doctors vs. homemakers and nurses. Dworkin's concept of luck does not address questions of why and how CEOs and doctors are more highly valued than homemakers and nurses. I contend that women's unequal situation is caused not simply because there are not as many female CEOs and doctors as male CEOs and doctors, but fundamentally because the work of child caring, nursing, cleaning, laundering, and cooking are largely devalued and under-recognized by society. Therefore, women's luck lies not in the fact that they are born as females, but in the gendered social structure that unjustly disadvantages women as a group and advantages men as a group, which Dworkin's concept of luck fails to address.

\section{Women's Chøice}

Luck egalitarians agree that people should be held responsible for the costs of choices 
that they make. This point, however, needs careful attention. Luck egalitarians do not simply say that people are responsible for all choices they make. Indeed, they specify that people should take personal responsibility for a certain type of choice, which I call autonomous choice. In identifying autonomous choices for which individuals should be held responsible, luck egalitarians provide various ideas. It is my purpose here to specify Dworkin's concept of autonomous choices and to apply them to women's choices in the family and at work.

According to Dworkin, a person's choice reflects her personality. He describes features of personality as preferences, tastes, convictions, and ambitions. On his account, those features of personality define "what a successful life would be like" for a person, and a person is held responsible for the design of a good life as defined by her personality. ${ }^{32)}$ In Dworkin's scheme of auction and hypothetical insurance markets under "equality of resources," the distribution of resources is sensitive to choices made by individuals about how to lead their lives.

Significantly, I want to highlight a qualification in Dworkin's notion of preference and choices. Dworkin says that the preferences that he considers in his theory need to be "authentic." He articulates that the preferences of people who engage in his auction and hypothetical insurance markets should be "authentic" - "true preferences of the agent." ${ }^{33}$ By "authentic" preferences, he means those preferences that accurately reflect a person's objective interests in leading her life. Dworkin admits that a person's personality is not static: it can change over time and place. He does take into account the possibility that the formation of personality is manipulated or misled by other people or circumstantial factors. In considering the principle of authenticity, Dworkin therefore seeks to identify the appropriate condition under which a person's personality is properly formed, reflected, and developed. ${ }^{34)}$ Therefore, given that the preferences of people are "authentic," they should be held responsible for the costs of the choices they make in accord with their preferences. Inequalities in resources among people resulting from their choices are justified under Dworkin's equality of resources. If women's choices to do housework and to take care of children are driven by their "authentic" preferences, Dworkin would claim that these choices of women are autonomous.

Relevant here is Alexander Kaufman's recent defense of luck egalitarianism against a

32) Dworkin, "Foundations of Liberal Equality," delivered as the 1998 Tanner lecture at Stanford University, reprinted in Stephen Darwall (ed.), Equal Freedom: Selected Tanner Lectures on Human Values (Ann Arbor: University of Michigan Press, 1995), p.277.

33) Dworkin, Sovereign Virtue, p.70.

34) Ibid., pp.159-61. 
prior criticism of it. ${ }^{35)}$ In an article entitled "What Is the Point of Equality?" Anderson argues that the notions of choice and responsibility employed by the luck egalitarian theorists do not adequately encompass the choices and the responsibilities of dependent caretakers, that is, those who provide physical and emotional support to others, especially family members, who are not capable of taking care of themselves. On Anderson's account, luck egalitarianism cannot handle certain conditions of dependent caretakers, such as vulnerability, poverty, and exploitation, when those conditions are the results of choices made by the caretakers themselves. She argues that, as long as women choose to have children and take care of their children, women will be caretakers; they will incur certain disadvantages from assuming that role; under luck egalitarianism, they cannot demand that their disadvantages be socially redressed. ${ }^{36)}$

In responding to Anderson's criticism, Kaufman claims that Anderson sometimes "mischaracterizes" and oversimplifies the nature of luck egalitarianism. ${ }^{37)}$ According to Kaufman, luck egalitarianism does not simply identify a person's preferences and all the resulting choices with autonomous choices for the costs of which she should be held responsible. In truth, luck egalitarianism is carefully concerned with the formation of preferences that determines whether or not the choices are actually autonomous. In particular, Kaufman points out that Dworkin in his equality theory intends preferences to be "authentic." Given such a confined definition of "preference," he considers a person to be responsible for the costs of choices resulting from her preferences. Kaufman adds that, if the (more generally defined) preferences of the caretakers are largely determined by "contingent and morally arbitrary social context," then those preferences are not categorized as "authentic" for Dworkin ${ }^{38)}$; if the caretakers' choices resulting from those preferences are not considered autonomous, he would not hold caretakers responsible for the costs of choices made on the basis of such preferences. Kaufman argues that, in such cases and in contrast to Anderson, luck egalitarianism provides for public assistance to caretakers even though their disadvantaged situations are the outcomes of their choices.

I do agree with Kaufman that Dworkin provides a more subtle and profound principle of equality than Anderson ascribes to them. I also agree with Kaufman that Dworkin, by acknowledging the possibility that the formation of preference is influenced, to a

35) Alexander Kaufman, "Luck, Responsibility, and Capabilities Equality," paper presented at the 2001 Annual Meeting of the American Political Science Association, San Francisco, August 30 - September 2, 2001.

36) Anderson, "What Is the Point of Equality?" pp.288, 297, 300, 311, and 324.

37) Kaufman, "Luck, Responsibility, and Capabilities Equality," p.4.

38) Ibid., p.15. 
significant degree, by arbitrary circumstantial factors, carefully defines the range of autonomous choices for whose cost a person should be held responsible. In essence, Kaufmann seems to acknowledge that Dworkin, to some extent, takes into account what Martha Nussbaum has described as the problem of "preference deformation." Nussbaum says that some people are unable to exercise a "critical scrutiny" of preferences and desires because "habit, fear, low expectations, and unjust background conditions" deform their preferences and desires. ${ }^{39)}$ If preferences are deformed and, thus, if it is impossible to exercise critical scrutiny of those preferences, the choices resulting from those preferences are not autonomous choices.

Kaufman's defense of luck egalitarianism, however, is inadequate to cover the choices of caretakers; it is insufficient to respond to Anderson's criticism. There are at least two problems with Kaufman's defense. First, whether the preferences of the caretakers are actually classified as "deformed preferences" - the unauthentic that Dworkin enumerates - and thus whether the caretakers are entitled to public assistance, as Kaufman claims, are problematic questions. Dworkin's authenticity principle focuses on legal circumstances under which people's preferences are formed. In describing the principle of authenticity, Dworkin distinguishes his idea of authenticity from "metaphysical" or "psychological" authenticity. He emphasizes that his idea of authenticity concerns only the "absence of legal constraints" in forming a person's personality. ${ }^{40)}$ Considering that the preferences of caretakers are influenced largely by socioeconomic and cultural factors rather than by legal factors, caretakers' preferences are properly not considered "authentic" in Dworkin's scheme, a fact that runs counter to Kaufman's claims.

Second, I question whether there exist any "authentic" preferences that express a person's own "true" or "genuine" self that are indifferent to or separate from the context of social circumstances and relationships. As I showed earlier, many of women's preferences/choices regarding taking care of children or other dependents or taking low-paid part-time/temporarily jobs are intrinsically contextualized within a social structure that is grounded in the gender division of labor in the family. This ultimately permits me to show that it is problematic to say that women necessarily make the types of autonomous/non-autonomous choices that Dworkin characterizes.

Indeed, women's preferences/choices are not only contextualized within, but also shaped and constructed by the gendered social structure grounded in the gender

39) Martha Nussbaum, Women and Human Development (Cambridge: Cambridge University Press, 2000), p.114.

40) Dworkin, Sovereign Virtue, p.483. 
division of labor. For example, the high price of public/private childcare, her husband's lack of available time to do housework and care for children, the difficulties she might encounter in getting and holding a full-time job and/or the relatively low wage she could be expected to earn all dynamically help to construct a women's preference for not working outside of the household at all or for taking a poorly paying part-time job that leaves time for housekeeping and childcare. In conclusion, women's choices regarding family and work are not perfectly categorized as "autonomous" choices led by "authentic" preferences; they are also not completely identified with "non-autonomous" choices driven by "deformed" preferences. Instead, they are largely choices that are socially constructed within the gendered social structure. Dworkin's concept of choice fail to capture this aspect of women's choice.

\section{The Systemic Relationship between Women's Luck and Women's Chøice}

So far I have argued that luck-egalitarian concepts of luck and choice do not properly capture the luck and choice of women situated in the family and at work. Now I offer another fatal limit of luck egalitarianism in its account of gender. Even if luckegalitarian notions of luck and choice were reformulated to encompass particular women's luck and women's choices, luck egalitarianism would ultimately still fail to address the systemic injustice of gender. This is because luck egalitarianism, which is fundamentally built upon the luck/choice distinction, cannot fully explain the intrinsic relationship between the gendered social structure and women's choices. In describing features of the systemic injustice of gender, I earlier explained that the relationship between the gendered social structure and women's choice is of major importance. The gendered social structure and women's choice are not independent each other. In contrast, the injustice of gender generated by the gender division of labor has been maintained and reinforced only through the systemic relationship between the gendered social structure and contextualized women's choice within the structure.

Some critics note that one of the chief problems of luck egalitarianism is that its distinction between luck and choice is ultimately unclear, particularly when applied to the real world. Scheffler, for example, says that "[the luck-egalitarian] distinction between choices and circumstances [luck] seems $\cdots$ to be both philosophically dubious and morally implausible" ${ }^{41)}$ In a similar vein, Alex Callinicos also holds that the luck /choice distinction fails to address the "complex" "relationship between choice, preferences

41) Scheffler, "What is Egalitarianism?" p.17. 
and circumstances," by giving an example of "adaptive preferences." According to Callinicos, just as preferences often adapt to circumstances, so preferences and choices are often formed in part or entirely under the influences of luck beyond people's control. ${ }^{42)}$ Although such points are well taken, my argument is not to point out simply the problematic distinction between luck and choice. That is, I am not questioning here the ultimate difficulty of drawing a line between luck and choice: for example, whether my preference for drinking beer derives 30 percent from genetic components inherited from my parents and 70 percent from my choice or 50 percent and 50 percent. Rather, in characterizing gender injustice generated by the gender division of labor in the family, I am concerned with the innate systemic connection between the gendered social structure and women's agency - how the gendered social structure is justified, maintained, and reproduced by women's agency and how women's agency is contextualized, shaped, and constructed by the gendered social structure.

\section{Conclusion: Toward a Feminist Theory of Equality}

The rise of luck egalitarianism in contemporary theories of social justice has drawn much scholarly attention. In spite of such great interest, especially among feminists, however, I have argued that luck egalitarianism ultimately is not a model that can contribute to conceptualizing a good feminist theory of equality. Luck egalitarianism, built upon the luck/choice distinction, has a "flawed understanding of the point of equality," as Anderson puts it. ${ }^{43)}$ I argue that the point of feminist equality is not only to address properly the systemic injustice of gender, but also to provide remedies for rectifying it. That is, the systemic analysis of gender is of central importance for conceptualizing a feminist theory of equality.

To conclude, I suggest four criteria that a good feminist equality should satisfy. First, feminist equality should consider the issue of gender to a product of human arrangements although it is beyond an individual's control. That is, the social relationship between women as a group and men as a group constitutes the issue of gender for which individual women and men have no particular responsibilities. A good feminist theory of equality should provide a normative principle to govern such a relationship between the genders (how women as a group should be positioned in

42) Alex Callinicos, Equality (Cambridge: Polity Press, 2000), pp.54-56. See also John Roemer, Theories of Distributive Justice (Cambridge, Mass.: Harvard University Press, 1996), chapter 7.

43) Anderson, "What is the point of equality?" p.288. 
relation to men as a group). Second, a feminist equality theory should recognize that factors like social norms and rules, practices, major institutions, cultural customs, socialization, and education all express in a certain way the social relationship between the genders. It should also recognize that these factors have to do with the distribution (and the process of distribution) of power, resources, prestige, and reputations between genders that results in the unequal status of the genders. Third, for the purpose of providing a normative principle of gender relationship, a feminist equality theory should thus offer a fundamental change in the social relationship between the genders, rather than redistributing the effects of the relationship, such as power, resources, prestige, and reputations. Fourth and finally, a feminist theory of equality should take the role of women's agency seriously. It should recognize that a woman's self is intrinsically social; her agency is shaped and constructed within the context of social conditions and relationships; and social relationships are essential for promoting women's autonomy. 


\section{REFERENCES}

Anderson, Elizabeth. Ethics 109 (1999): 287-337. 1999.

Arneson, Richard. "Feminism and Family Justice." Public Affairs Quarterly 11: 313-330. 1997.

Becker, Gary. A Treatise on the Family. Cambridge, Mass.: Harvard University Press. 1981.

Berger, Curtis and Joan Williams. Property: Land Ownership and Use. New York: Aspen. 1997.

Bureau of Labor Statistics. Employment and Earnings.

Bureau of the Census. Current Population Surveys.

Callinicos, Alex. Equality. Cambridge: Polity Press. 2000.

Dworkin, Ronald. "Foundations of Liberal Equality." Delivered as the 1998 Tanner lecture at Stanford University. Reprinted in Stephen Darwall (ed.). Equal Freedom: Selected Tanner Lectures on Human Values. Ann Arbor: University of Michigan Press. 1995.

Dworkin, Ronald. Sovereign Virtue. Cambridge, Mass.: Harvard University Press. 2000.

Catalyst. 2000 Catalyst Census of Women Corporate Officers and Top Earners. New York: Catalyst Publication. 2000.

Folbre, Nancy. Who Pay for the Kids?: Gender and the Structures of Constraint. London and New York: Routldge. 1994.

Furchtgott-Roth, Diana and Christine Stolba. Women's Figure: An Illustrated Guide to the Economic Progress of Women in America. Washington, D.C., AEI Press. 1999.

Giddens, Anthony. The Constitution of Society: Outline of the Theory of Structuration. Berkeley and Los Angeles: University of California Press. 1984.

Guest, Stephen. Ronald Dworkin. Edinburgh: Edinburgh University Press. 1992.

Hinton, Timothy. "Must Egalitarians Choose Between Fairness and Respect?" Philosophy \& Public Affairs 30: 72-87. 2001.

Kaufman, Alexander. "Luck, Responsibility and Capabilities Equality," Paper presented at the 2001 Annual Meeting of the American Political Science Association, San Francisco, August 30 - September 2. 2001.

Kim, Hee-Kang. "A Feminist Critique of the Luck Egalitarian Concept of Autonomy." Korean Political Science Review 42, 3 (Fall): 79-101 [Korean] 2006. 
Macleod, Colin. Liberalism, Justice, and Markets: A Critique of Liberal Equality. Oxford: Clarendon Press. 1998.

Mason, Andrew. "Equality, Personal Responsibility, and Gender Socialisation.” Proceedings of the Aristotelian Society 100: 227-46. 2000.

New Strategist Editors. American Women: Who They Are \& How They Are. $2^{\text {nd }}$ edition. Ithaca, New York: New Strategist Publications, Inc. 2002.

Nussbaum, Martha. Women and Human Development. Cambridge: Cambridge University Press. 2000.

Okin, Susan. Justice, Gender, and the Family. New York: Basic Books. 1989.

Rhode, Deborah. Speaking of Sex: The Denial of Gender Inequality. Cambridge, Mass.: Harvard University Press. 1997.

Rhode, Deborah. "Gender and the Profession" The No-Problem Problem," Hofstra Law Review. 30. 2001.

Robeyns, Ingrid. "Does the Gender Division of Labor Result in Unjust Inequalities?" Paper Presented at the 2003 Annual Meeting of the American Political Science Association, Philadelphia, August 28-August 31. 2003.

Roemer, John. Theories of Distributive Justice. Cambridge, Mass.: Harvard University Press. 1996.

Scheffler, Samuel. "What is Egalitarianism?" Philosophy and Public Affairs 31 (2003): 4-39. 2003.

The Families and Work Institute. Highlights of the National Study of the Changing Workforce. 3. 2002.

Williams, Joan. "Notes of a Jewish Episcopalian: Gender a language of Class, Religion as a Dialect of Liberalism.” In Anita Allen \& Milton Regan (eds.). Debating Democracy's Discontent: essays on American Politics, Law, and Public Philosophy. Oxford: Oxford University Press. 1998.

Williams, Joan. Unbending Gender: Why Family and Work Conflict and What to Do About It. Oxford: Oxford University Press. 2000.

Wolff, Jonathan. "Fairness, Respect, and the Egalitarian Ethos." Philosophy \& Public Affairs 27: 97-122. 1998. 